\title{
New Discovery of Late Pleistocene Vertebrate Fossils from the Thimi Formation, Bhaktapur, Nepal
}

\author{
Khum N. Paudayal \\ Central Department of Geology \\ Tribhuvan University, Kirtipur, Kathmandu, Nepal \\ E-email: khum99@gmail.com)
}

\begin{abstract}
The fluvio-deltaic deposit of the Thimi Formation constitutes the uppermost part of the sedimentary sequence in the Kathmandu Basin, and is consists of carbonaceous clay, diatomaceous clay, silty-clay, silt, fine to medium grained sand, and thin to medium lignite beds. A $25 \mathrm{~m}$ thick fresh surface exposure of this formation at Phaidhoka, Bhaktapur yielded significant number of vertebrate fossils. The vertebrate fossils recovered from a sand bed at $14 \mathrm{~m}$ from the bottom of the sequence consist of six teeth. The teeth were identified as Bovid teeth. Along with Bovid molars fragments of limb and pelvic bones were also found belonging to the same individual.
\end{abstract}

Keywords: Bovid molars, Kathmandu Basin, Late Pleistocene

\section{INTRODUCTION}

The Kathmandu intermontane basin is filled with very thick sequence of lacustrine and fluvial deposits of PlioPleistocene age (Yoshida \& Igarashi 1984, Moribayashi \& Mauro 1980). The oldest formation is known as Lukundol Formation exposed to the southern part of the basin. The primary basin was mainly confined to the southern part of the valley and was relatively small compared to the later. It started receiving sediments from the southern part and Lukundol Formation was formed in depositional the process (Kizaki 1994). But the uplifting of Mahabharat Range in the southern part changed the course and the lake started shifting towards north. The tilting of the beds of the Lukundol Formation to the north is one of the major evidence. The new lake was much large and covered large area resulting in the deposition of younger sediments named as Gokarna, Thimi and Patan Formations (Fig. 1). The lake completely drained at the end of the last glacial epoch (Yoshida \& Igarashi 1984). The Thimi Formation, a fluviolacustrine deposit, is distributed around Pashupatinath, Tribhuvan International Airport, Thimi, Bhaktapur and Patan comprises alternating layers of carbonaceous and diatomaceous clay, silty clay, silt and fine to coarse grained sand. Yoshida and Igarashi (1984), Igarashi et al. (1988), and Yoshida and Gautam (1988) divided the basin sediments into the older-stage deposits (i.e. the Lukundol Formation), middle-stage deposits (i.e. the Boregaon, Chapagaon and Pyanggaon terrace deposits), and younger-stage deposits (i.e. the Gokarna, Thimi and Patan Formations). Different authors reported various kinds of vertebrate remains from the Lukundol, Gorkarna and Thimi Formations (Sharma 1973, West \& Munthe
1981, Corvinus \& Sharma 1984, Dongol 1985, West et al. 1988, Sah et al. 1995-96, Paudayal et al. 2011). The history of finding vertebrate fauna in the Kathmandu Basin is summarized in Paudayal et al. (2011). In this paper new vertebrate remain discovered from the Thimi Formation in the Bhaktapur area will be discussed briefly.

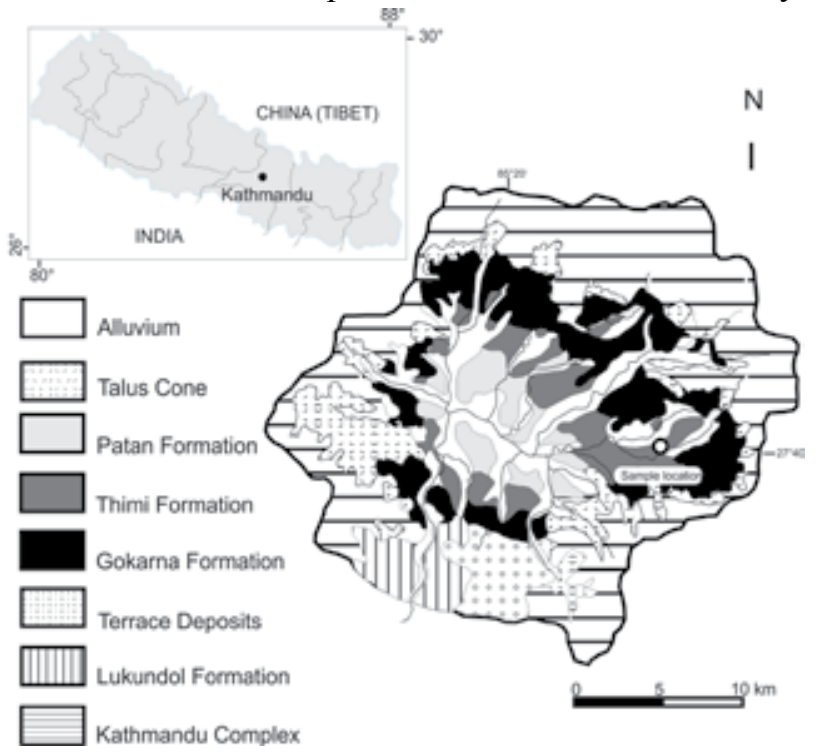

Fig. 1. Geological map of the study area with fossil location (black open cirlce) at Phaidhoka, Bhaktapur, Nepal.

\section{MATERIALS AND METHODS}

The Thimi Formation exposed at Phaidhoka, Bhaktapur is $25 \mathrm{~m}$ thick (Fig. 2). This is a sand quarry lying at the left side of Chyamasingh to Nala road. The sediments are relatively finer indicating the deposition might have 
occurred from suspension settling. The thin, parallel laminations of alternating silt, silty clay indicate widespread deposition from suspension over the sand beds. The sand and silt layer consists of cross bedded structure; wave ripple laminated structure and sometimes with the distortion of ripples in sand beds. The flow structure and distorted cross beds suggest the liquefaction or fluidization and hydro-plastic deformation. The deformation was considered to have been caused by paleo-earthquakes during sedimentation. The vertebrate fossils were collected from the surface exposure. The sand matrix around the fossils was removed by brush and identified at Senckenberg Research Institute and Natural History Museum, Frankfurt am Main, Germany. The specimens are stored at the Central Department of Geology Museum, Tribhuvan University, Kirtipur, Kathmandu, Nepal.

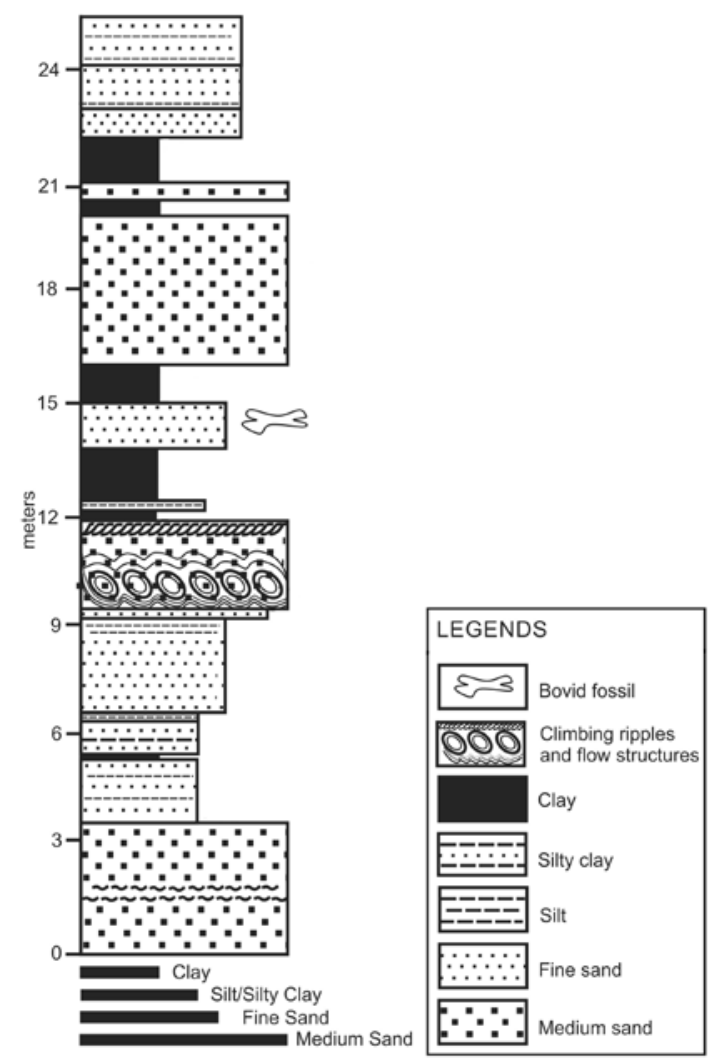

Fig. 2. Lithology of the Thimi Formation, Phaidhoka section, Bhaktapur, Nepal (with Bovid fossil horizon).

\section{RESULTS}

\section{Vertebrate Fossil}

Fossil Material: Bovid molars and incisor (Plate:1)

Locality: Phaidhoka, Bhaktapur

Age: Late Pleistocene

Systematics Description

Class: Mammalia Linn., 1758 -Mammals
Order: Artiodactyla Owen, 1848

Family: Bovidae Gray, 1821

Genus: Bos Linn., 1758

Species: indet.

\section{CONCLUSION}

Six large teeth along with fragmented limb and pelvic bones belonging to family Bovidae (Genus Bos) were discovered from the middle part of the section. The fossil taxon clearly represents a browser, although it may take also a limited amount of grasses at the times. It is not extremely specialized in its diet. In this respect, like in many others, it resembles to genus Bos and seems to be a fossil precursor.

\section{ACKNOWLEDGEMENTS}

I would like to express my sincere thanks to Prof. Dr. Lalu Paudel, head of the Central Department of Geology, Tribhuvan University (CDG, TU) Kirtipur, for his support and co-operation to carry out this research at CDG, TU. I would also like to thank Christine Hertler (Senckenberg Research Institute and Natural History Museum, Frankfurt am Main, Germany) for her help for the identification of fossil materials.

\section{REFERENCES}

Corvinus, G., Sharma, J.L. 1984. A vertebrate fossil find in the Kathmandu Valley. Ancient Nepal 82: 2732.

Dongol, G.M.S. 1985. Geology of the Kathmandu fluviatile lacustrine sediments in the light of new vertebrate fossil occurrences. Journal of Nepal Geological Society 3: 43-57.

Igarashi, Y., Yoshida, M., Tabata, H. 1988. History of Vegetation and Climate in the Kathmandu Valley. Proceedings of Indian Natural Science Academy 54A(4): 550-563.

Kizaki, K. 1994. An Outline of the Himalayan Upheaval, a case study of the Nepal Himalaya. JICA (Japan International Cooperation Agency), 127p.

Moribayashi, S., Maruo, Y. 1980. Basement topography of the Kathmandu Valley, Nepal-An application of gravitational method to the survey of a tectonic basin in the Himalayas. Journal of the Japan Society of Engineering Geology 21: 30-37.

Paudayal, K.N., Panthee, S., Hertler, C. 2011. A bovid specimen from Late Pleistocene deposits in the Kathmandu Basin, Nepal. Journal of Stratigraphic Association of Nepal 7: 9-14.

Sah, R.B., Paudel, M., Ghimire, D. 1995-96. Lithological successions and some vertebrate fossils from the fluviolacustrine sediments of the Kathmandu 


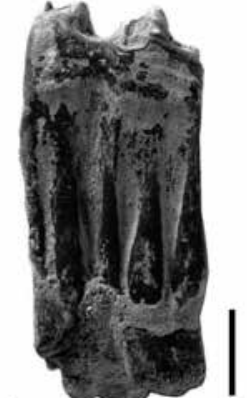

$1 a$.

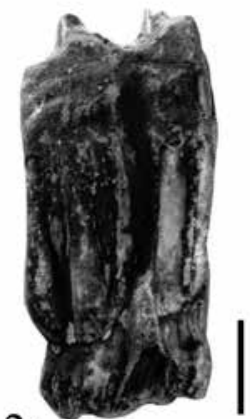

$2 a$.

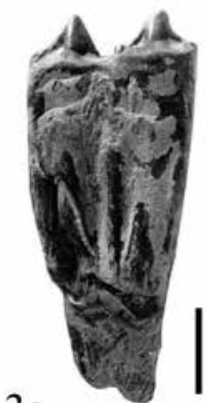

$3 a$.

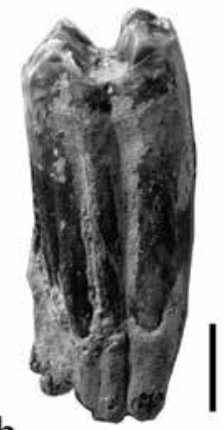

$1 b$.

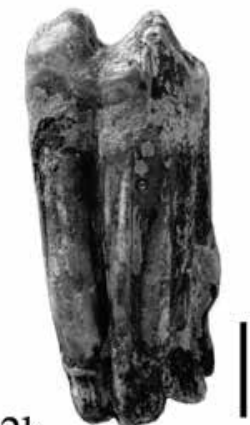

$2 b$.

$3 b$.

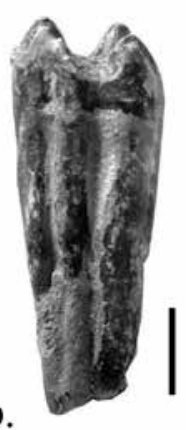

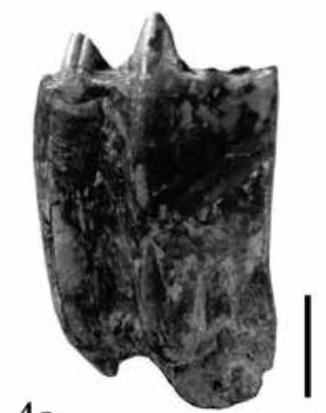

4a.

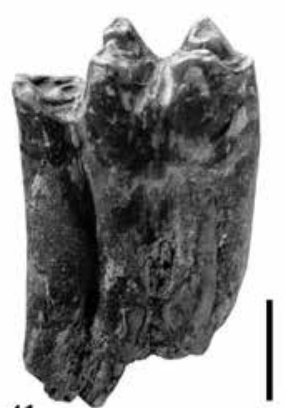

$4 b$.

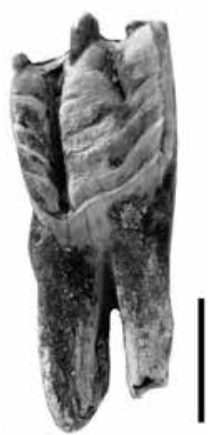

$5 a$.

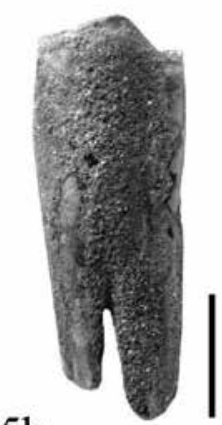

$5 b$.

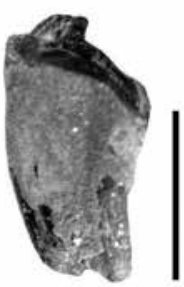

$6 a$.

$6 b$

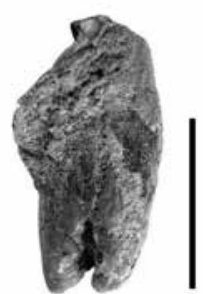

Plate: 1. Lingual view (1a, 2a, 3a, 4a, and 5a) and buccal view (1b, 2b, 3b, 4b and 5b) of Bovid molars. A fragment of lower central incisor $(6 \mathrm{6}, \mathbf{6 b})$. Scale bar $=2 \mathrm{~cm}$.

Valley, Central Nepal. Nahson Bulletin 5-6: 2127.

Sharma, C.K. 1973. Geology of Nepal, Man Ram Sharma, Kathmandu, Nepal.

West, R.M., Munthe, J. 1981. Neogene vertebrate Palaeontology and Stratigraphy of Nepal. Journal of Nepal Geological Society 1: 1-14.

West, R.M., Dongol, G.M.S., Munthe, J., Hutchinson, J.H. and Gupta, V.J. 1988. Late Neogene and Quaternary Geology, Palaeontology and Palaeoenvironment of the Kathmandu Valley, Central Nepal and the Churia Hills, Western Nepal. In The Palaeoenvironment of East Asia from the Mid-Tertiary, Proceedings of the Second Conference (Ed. P. Whyte) II: 916-936.

Yoshida, M., Gautam, P. 1988. Magnetostratigraphy of Plio-Pleistocene lacustrine deposits in the Kathmandu Valley, central Nepal. Proceedings of Indian Natural Science Academy 54A(30): 410-417.

Yoshida, M. and Igarashi, Y. 1984. Neogene to Quaternary Lacustrine sediments in the Kathmandu Valley, Nepal. Journal of Nepal Geological Society 4: 73-100. 